\title{
GMNN wt Allele
}

National Cancer Institute

\section{Source}

National Cancer Institute. GMNN wt Allele. NCI Thesaurus. Code C49530.

Human GMNN wild-type allele is located in the vicinity of $6 p 22.2$ and is approximately 11

$\mathrm{kb}$ in length. This allele, which encodes geminin protein, plays a role in the regulation of

DNA replication during both the $\mathrm{S}$ and G2/M phases of the cell cycle. 